\title{
Genetic and environmental factors affecting 305-day mature equivalent milk yield of Holstein Friesian cows in the United Arab Emirates
}

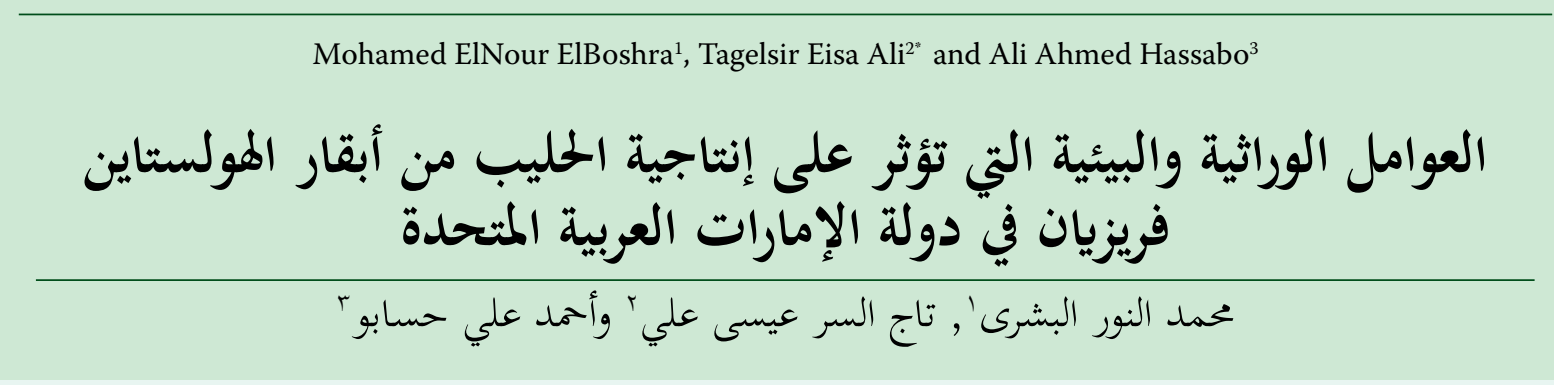

AвStract. The main objective of this research was determining the effect of sire of cow, year and season of freshening, lactation number, and their different interactions on 305-day mature equivalent (ME) milk yield of Holstein Friesian cows in the United Arab Emirates (UAE). It also aimed to estimate sire and error variance and heritability of 305-day $M E$ milk yield. The data was collected from AL Salamat Dairy Farm in Al Ain. The average size of the herd was 1000 animals during the experimental period. The Dairy Comp 305 computer program was used for compiling the data. The data under the study covered the years 2004 to 2007. The climatic temperature during the summer (April to September) varied from moderate to very hot. The winter (October to March) had lower temperature and higher relative humidity than the summer. All the effects were fixed except for random sire and residual error term. The overall least-square mean of the 305-day $M E$ milk yield was $11060 \pm 355 \mathrm{~kg} / 305$ days. The data showed a significant effect of sire of cow $(\mathrm{p} \leq 0.001)$, year of freshening $(\mathrm{p} \leq 0.001)$, lactation number $(\mathrm{p} \leq 0.01)$, year $\mathrm{x}$ season of freshening $(\mathrm{p} \leq 0.01)$, and year of freshening $x$ lactation number $(\mathrm{p} \leq 0.001)$ on milk yield. However, the effect of season of freshening showed non significant effect. No significant seasonal differences were found in 2004. However, in the year 2005 and 2006, the summer fresheners had significantly higher yield than those of the winter season. The 305-day $M E$ pertaining to summer $v s$. winter were $11691 \pm 400 \mathrm{~kg} v s .11483 \pm 410 \mathrm{~kg}$ and $11522 \pm 369 \mathrm{~kg} v s .11041 \pm 374 \mathrm{~kg}$ for the year 2005 and 2006, respectively. However, the reverse was true in 2007 with the fresheners during summer that have lower 305-day $M E(10286 \pm 372 \mathrm{~kg})$ than those freshening during winter $(10672 \pm 388 \mathrm{~kg})$. The differences among the three lactations were relatively high in 2004 (9837 to $12116 \mathrm{~kg}$ ), compared to 2005 - 2006 (11267 to $11747 \mathrm{~kg}$ ) and 2007 (9853 to $11355 \mathrm{~kg}$ ). The heritability of 305-day $M E$ was 0.31 indicating that a significant response to selection would be achieved through a well-designed progeny testing and cow evaluation program.

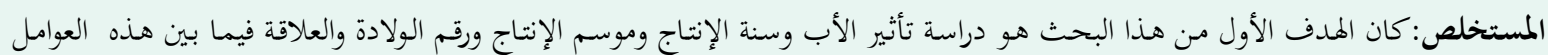

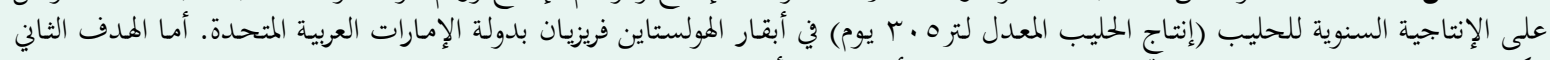

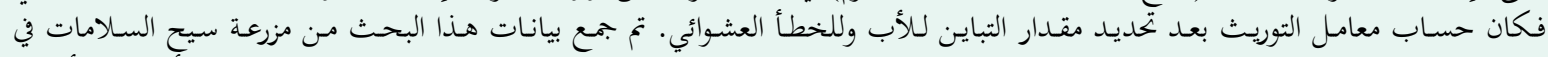

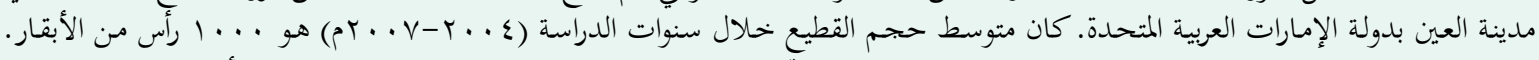

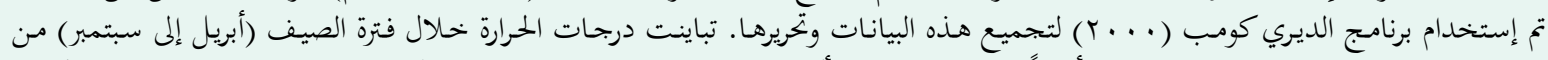

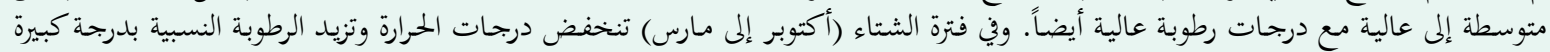

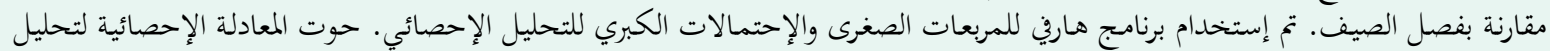

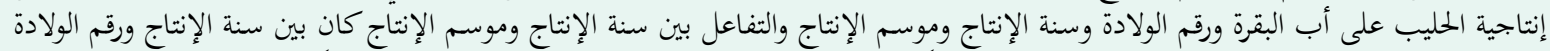

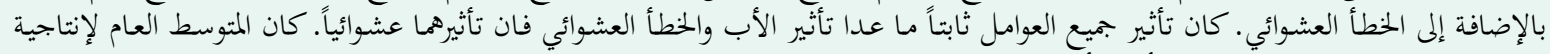

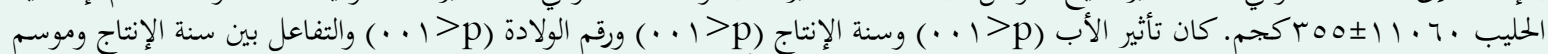

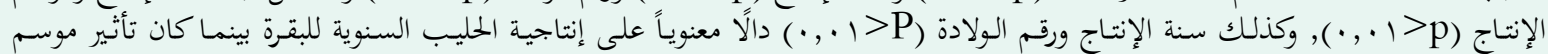

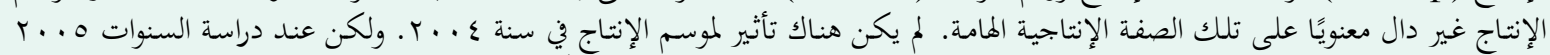

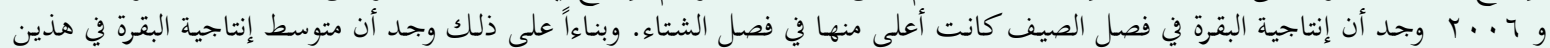

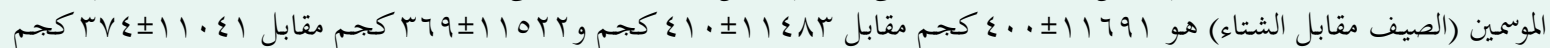

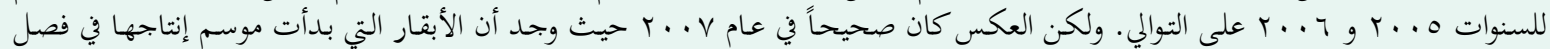

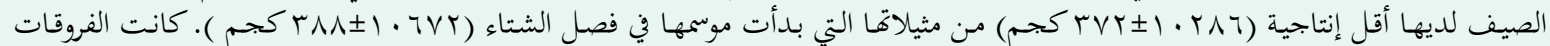

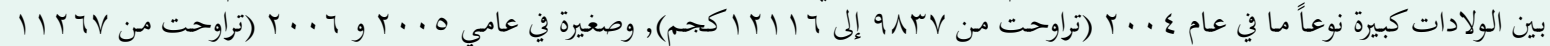

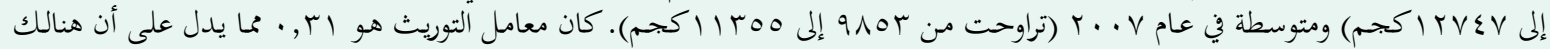

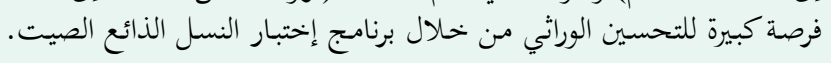

الكلمات المفتاحية: دولة الإمارات العربية المتحدة ، أبقار حليب ، هولستاين فريزيان، انتاج الحليب ، البيئة

1 AlAin Dairy Farm, AlSalamat dairy farm, AlAin, UAE.

$2^{*}$ Tagelsir Eisa Ali ( ${ }^{2}$ Dept of Presidents' Affairs AlAin, MNC,

AlAin,UAE. email: tagali@hotmail.com

${ }^{3}$ AlNileen University, Faculty of Agriculture science, Khartoum, Sudan. 


\section{Introduction}

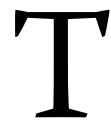
here is an increasing demand of animal products in all countries around the world. However these demands exert more pressure on the countries in the arid zone to increase the animal production (Philip, 2010). It is well-known that the indigenous cattle are low-producing animals. Thus, almost all the countries in the tropics and sub-tropics have imported high milk producing cattle from temperate zone. The dairy cattle such as Friesian and Holstein-Friesian are the most commonly imported cattle. AL Ain Dairy Farm is a leading dairy company in UAE. Several problems have been encountered in raising these animals in the tropics. Heat stress was one of the most important problem (Yousef, 1985). Furthermore, Yousef (1985) defined heat stress as the magnitude of forces external to the body system which tend to displace its system from their resting or ground state. Climate is a combination of elements that include temperature, humidity, rainfall, air movement, radiation, barometric pressure, and ionization (Johnson, 1987). The relationship between the animal and environment determines the degree to which the animal remains in thermal equilibrium with its environment (Finch, 1976). Effects of heat stress are more severe in hot humid climates, but dairy cattle raised in areas with relatively moderate climates are also exposed to periods of heat burden. So the thermal environment is a major factor that affects milk production and reproductive performance of dairy cows especially in animals with high genetic merit (Koppock et al,1982).

Dairy cattle research tended to concentrate on genetic improvements in order to increase milk production. Little attention had been paid to the thermoregulatory ability of the modern cow, as her capacity to produce milk (Murphy et al. 1983). Tao and Dah (2013) reported that cows which were heat stressed during late gestation have impaired mammary growth before parturition and decreased milk production in the subsequent lactation. Ray (1992) found that milk production was depressed for cows calving in summer and fall. Heat stress threatens the normal metabolic balance and usually produces positive feedback, which affects the performance of the animal when the heat exceeds the upper critical temperature (UCT).

High producing cows are affected more than low producing and dry cows as the thermonuteral zone (TNZ) shifted down as milk production, feed intake, and heat production increased (Koppock et al, 1982). Johnson et al. (1963) showed that cows consumed less feed as ambient temperature and combined ambient temperature and percent relative humidity $(\mathrm{RH})$ were increased. Berman et al. (1985) suggested that the upper limit of ambient temperatures at which Holstein cattle may maintain a stable body temperature was 25 to $26^{\circ} \mathrm{C}$, and that above $26^{\circ} \mathrm{C}$, practices should be instituted to minimize the rise in body temperature. However, in the humid area, one of the major challenges is the combined effects of high $\mathrm{RH}$ with high ambient temperature. When the temperature reaches $29^{\circ} \mathrm{C}$ with $40 \% \mathrm{RH}$ the milk yield of Holstein, Jersey and Brown Swiss cows was 97\%, 93\%, and $98 \%$ of the normal yield, respectively. But when the $\mathrm{RH}$ was increased to $90 \%$, the yields of these breeds decreased to $69 \%, 75 \%$, and $83 \%$ of the normal values, respectively (Binaca, 1965).

Knowledge of other non-genetic factors that influence production is important for better assessment of genetic ability of dairy farm. Knowledge of the interaction between genetics and environment is also very important for successful selection and progeny testing programs. Moreover increased milk production can be achieved by implementation of environmental modification such as installation of cooling facilities through shades, water spray, and fans (Armstrong 1994). Furthermore, Armstrong (1994) stated that the economic benefit should be determined before installing these equipments to reduce heat stress. A point to mention is that environmental modifications can not only be used to protect the animals, but they can also be used to protect dairy products from deterioration of their quality. Intawiwat et al. (2013) developed green polyethylene film for protection of dairy products to reduce degradation of photosensitizers. Beede and Collier (1986) and Chase (2005) identified three management strategies to minimize the effects of heat stress: physical modification of the environment (shading and cooling), genetic development of heat-tolerant breeds and improved nutritional management practices.

For accurate selection of bull and better evaluation of dairy farms, 305-day $M E$ milk yield was used. The 305-day $M E$ milk yield is the standardized milk yield according to some factors. The most important factors in this standardization are lactation length, calving age and milking frequency (Suleyman, 2006). Standardizing records according to these factors will raise accuracy in selection as they reflect the genetic structure of animals. This method is also important for proper evaluation of strength of the cow in milk production as well as estimation of the excepted of subsequent lactations yield ( $\mathrm{Su}$ leyman, 2006). While superior bulls or cows are being selected for breeding, their ability to transfer this genetic merit to their progeny should be considered by breeders. In simple terms heritability (h2) measures the degree to which the phenotypic value of an individual reflects the actual genetic merits of that individual.

This study focuses on the performance of the Holstein Friesian cows in the United Arab Emirates with the following specific objectives:

1-To determine the effect of sire of cow, lactation number, year of freshening, season of freshening, and year $\mathrm{X}$ season of freshening, and year of freshening $X$ lactation interaction on 305-day $M E$ milk yield of the Holstein Friesian cows in UAE.

2-To estimate heritability of 305-day $M E$ milk yield 
using sire and residual variance components for $\mathrm{Hol}$ stein Friesian in UAE.

\section{Materials and methods}

\section{Area of study and climate}

This study was conducted in Sei'h AL Salamat Dairy Farm which is one of AL Ain Farms for Livestock and Animal Production. It is located in Al Ain city, found in the eastern part of UAE. This farm was initially established in 1987 with 300 milking cows. Now the farm has 1000 milking cows and 750 rearing heifers for replacement.

The latitude at Sei'h AL Salamat Dairy Farm area is $24^{\circ} 12^{\prime} \mathrm{N}$ and the longitude is $55^{\circ} 46^{\prime} \mathrm{E}$. The ambient temperature, relative humidity and rainfall were taken from AL Ain Weather Station, located in the same farm area. Climatic condition in the UAE is generally hot and humid during April to September and warm to cool from October to March. The RH throughout the year is high in the coastal area and decreases gradually toward the interior region. $\mathrm{Al}$ Ain city is about $200 \mathrm{~km}$ away from the costal area, so it is less humid than the costal area. The maximum temperature during the period of study gradually increased from $26.6^{\circ} \mathrm{C}$ in January and reached the peak of approximately $44.0^{\circ} \mathrm{C}$ during the period from June to August and then declined gradually to reach $27.2^{\circ} \mathrm{C}$ in December. On the other hand the maximum RH started with a peak of $93 \%$ in January and declined to the lowest value; of approximately $62 \%$; during May to August, then gradually increased to reach 91\% in December. These results indicated that the months with high maximum temperature has low $\mathrm{RH}$ and this was very important and helpful in the use of evaporative cooling system. Similar tendency were observed with the minimum monthly temperature and $\mathrm{RH}$ months.

\section{Management system}

According to the routine management based on personal communication with the farm managers, the breed of cattle studied was Holstein Friesian. The sheds were free-stall and each was 72x63 meters in dimension and accommodated 125 cows. The shaded area was $15.5 \%$ of the total area of the shed. The space between adjacent sheds was 4.5 meters wide and it was roofed and used as feeding area. All the cows' standing and feeding area were covered with concrete. The sheds were equipped with fans, sprinkles and Korral Kool system (American Cooling System using sprinkles and fans controlled by a computer). During the years of the study (2004-2007), all the different groups of cows were covered with the cooling system. Cow shower was fixed at the exit of milking parlor.

The cows were fed total mixed ration (TMR) which was formulated in the farm according to the need of the different cow groups. The cows were milked four times a day. The daily milk yield per cow was measured two times a month. Drinking water was available on a 24hour basis, providing eight inch as water space per cow. Intensive management practices were implemented in order to counteract the heat stress. Dairy Comp 305 program (Valley Agricultural Software, 2000) was used for cow management. The program monitored milk production, conception rate, pregnancy rate, culling rate and $M E$ milk yield calculation.

\section{Animal health and vaccination}

Based on the personal communication with the veterinarian in charge, the program of treatment and vaccination against infectious disease (e.g. Foot and Mouth Disease, Rinder Pest, Clostridium, Brucela, Rota Virus, Corona Virus and E coli) was designed and applied by qualified staff. Sick animals were isolated and treated. The application of preventive measurement was started at the gate of the farm by good bio-security and foot and wheel bath. The cow sheds were cleaned three to four times daily. The flies and insects were controlled by AL Ain Municipality. Samples specimens were sent to the laboratory for investigation when necessary. The farm received feedback report from the milk factory showing the composition analysis and microbiology counting of total Bacteria and Coli-form for the farm raw milk on daily basis. Corrective action was taken if necessary.

\section{Data collection}

The data for the current study were collected from Se'h Al Salmat Dairy Farm, during the years 2004 to 2007 inclusive. Cow milk record consisted of cow identification

Table 1. Distribution of $M E$ yield records by year $x$ season of freshening subclass ${ }^{1}$.

\begin{tabular}{|c|c|c|c|}
\hline \multirow{2}{*}{ Year of Freshening } & \multicolumn{2}{|c|}{ Season of Freshening } & \multirow{2}{*}{ Total } \\
\hline & Summer & Winter & \\
\hline 2004 & 47 & 57 & 104 \\
\hline 2005 & 110 & 107 & 217 \\
\hline 2006 & 227 & 166 & 393 \\
\hline 2007 & 323 & 114 & 437 \\
\hline Total Records & 707 & 444 & 1151 \\
\hline
\end{tabular}


Table 2. Analysis of variance for 305-day ME milk yield ${ }^{1}$.

\begin{tabular}{|c|c|c|c|c|}
\hline Source & d.f. & Sum of Square & Mean squares & P-value \\
\hline Sire of cow & 49 & 331659687 & 6768565 & $* *$ \\
\hline Year of freshening & 3 & 112576245 & 37525415 & $* * *$ \\
\hline Season of freshening & 1 & 800652 & 800652 & NS \\
\hline Lactation number & 2 & 25277098 & 12638549 & $\because *$ \\
\hline Year X Season & 3 & 32795915 & 10931972 & $\because *$ \\
\hline Year X Lactation & 6 & 116558474 & 19426412 & :*:* \\
\hline Residual error & 1086 & 2968086550 & 2733045 & \\
\hline
\end{tabular}

${ }^{1 *} \mathrm{P} \leq 0.05,{ }^{* *} \mathrm{P} \leq 0.01{ }^{* * *} \mathrm{P} \leq 0001, \mathrm{NS}=$ Not significant

number (ID), sire ID, dam ID, cow date of birth, cow date of calving, cow lactation number, days open, ME milk yield and days in milk. The data were thoroughly edited and records with missing information were discarded. The total numbers of cow records which were used to determine the genetic and environmental factors affecting 305-day $M E$ milk yield as well as to estimate heritability for this economically important trait were 1151 record distributed by year and season of freshening (Table 1).

\section{Statistical analysis}

The statistical model which was used to analyze the 305day $M E$ milk yield data is presented as follows:

$\mathrm{Y}_{\mathrm{ijklm}}=\mu+\mathrm{s}_{\mathrm{i}}+\mathrm{a}_{\mathrm{j}}+\mathrm{b}_{\mathrm{k}}+\mathrm{c}_{1}+\mathrm{ab}_{\mathrm{jK}}+\mathrm{ac}_{\mathrm{jl}}+\mathrm{e}_{\mathrm{ij} \mathrm{klm}}$

Where $\mathrm{Y}_{\mathrm{ijklm}}={ }_{\mathrm{ij} \mathrm{klm}}^{\text {th }} M E$ milk yield/cow.

$\mu=$ fixed mean constant to all observation.

$\mathrm{s}_{\mathrm{i}}=$ effect of $\mathrm{i}^{\text {th }}$ sire of cow for $\mathrm{i}=1$ to 50 (random)

$a_{j}=$ effect of $j^{\text {th }}$ year of freshening group for $j=2004$ to 2007 (fixed)

$b_{k}=$ effect of $k^{t h}$ season of freshening group for $\mathrm{k}=1$ for summer and 2 for winter (fixed)

$c_{1}=$ effect of $1^{\text {th }}$ lactation number for $\mathrm{l}=1$ to 3 (fixed)

$\mathrm{ab}_{\mathrm{jk}}=$ effect of $\mathrm{jk}^{\text {th }}$ year $\mathrm{X}$ season of freshening interaction (fixed)

$\mathrm{ac}_{\mathrm{jl}}=$ effect of $\mathrm{jl}^{\text {th }}$ year of freshening X lactation number interaction (fixed)

$\mathrm{e}_{\mathrm{ijklm}}=$ effect of $\mathrm{ijklm}^{\text {th }}$ residual error term (random).

First, conventional analysis of variance was carried out with all the factors assumed to be fixed except for the random residual error term. Then, Harvey Least square

Table 3. Estimation of variance components and heritability of 305d ME milk yield ${ }^{1}$.

\begin{tabular}{ll} 
Source & Value \\
\hline Sire Variance $\left(\sigma_{\mathrm{s}}^{2}\right)$ & 230137 \\
Residual Variance $\left(\sigma_{\mathrm{e}}^{2}\right)$ & 2733045 \\
Heritability $\left(\mathrm{h}^{2}\right)$ & 0.31 \\
${ }^{1} \mathrm{~h}^{2}=\left(4 \sigma \mathrm{s}^{2} / \sigma \mathrm{s}^{2}+\sigma \mathrm{e}^{2}\right)$ &
\end{tabular}

and Maximum Likelihood Computer Program (1988) was used to fit this model (model 2) and also to estimate the sire $\left(\sigma_{\mathrm{s}}^{2}\right)$ and error $\left(\sigma_{\mathrm{e}}^{2}\right)$ variance components. For the variance component estimation, the sire of cow and residual error variance term were assumed to be random and have the following distribution $\mathrm{N} \sim\left(0, \sigma_{\mathrm{s}}^{2}\right)$ and $\mathrm{N} \sim$ $\left(0, \sigma_{\mathrm{e}}^{2}\right)$, respectively. The sires were un-related and errors un-correlated.

The heritability $\left(\mathrm{h}^{2}\right)$ of 305-day $M E$ milk yield was estimated as follows:

$$
h^{2}=4 \sigma_{\mathrm{s}}^{2} /\left(\sigma_{\mathrm{s}}^{2}+\sigma_{\mathrm{e}}^{2}\right)
$$

\section{Results}

\section{Factors affecting 305-day ME milking yield}

Results in Table 2 show that the effects of sire of cow $(\mathrm{P} \leq$ $0.001)$, year of production ( $\mathrm{P} \leq 0.001)$ and lactation number $(\mathrm{P} \leq 0.01)$ were significantly affecting $M E$ milk yield. Furthermore, the effects year $\mathrm{X}$ season of freshening ( $\mathrm{P}$ $\leq 0.01)$ and year of freshening $X$ lactation number $(P \leq$ 0.001 ) interactions were also highly significant. However, the effect of season of freshening had non significant $(P>0.05)$ effect. Since the interactions had significant effect on $M E$ mild yield, then the main effect of the individual factors has little value and will not receive any further discussion. The least-square means for the effect of year $\mathrm{X}$ season of freshening and year of freshening $\mathrm{X}$ lactation number interactions were also depicted on figures 1 and 2 respectively.

\section{Heritability of 305-day ME Milk Yield}

The heritability of milk yield measures the portion of the genetic merit that is transferred from the parent to their progeny. In the present study, a sire model was used and maximum likelihood method was utilized to estimate sire and error variance components. The result in Table 3 shows that the heritability for $M E$ Mature Equivalent milk yield was 0.31 . 


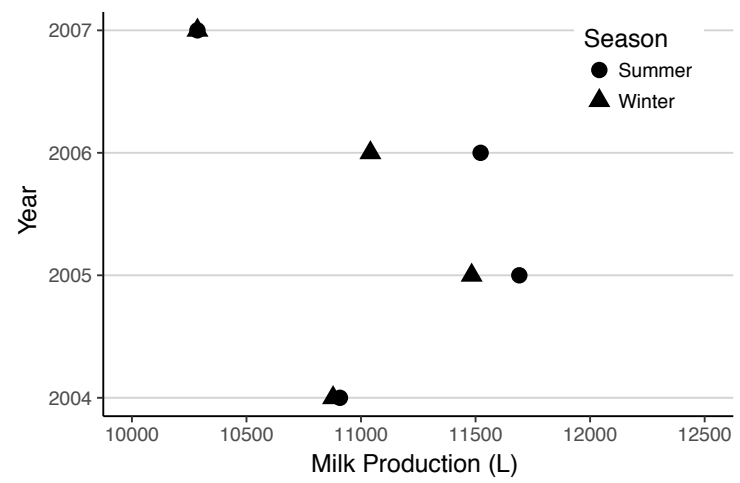

Figure 1. Effect of year and season of freshening on 305day $M E$ milk yield.

\section{Discussion}

Results indicated that the effects of year of freshening $(\mathrm{P} \leq 0.001)$ and lactation number $(\mathrm{P} \leq 0.01)$ on $305-$ day $M E$ milk yield were highly significant. This finding is close to that of Suleyman (2009) who used the same Least-square method to analyze milk yield of Holstein cows in Turkey. The interaction of year X season of freshening on 305 day- $M E$ milk yield was highly significant ( $P$ $\leq 0.01$ ). Similar results were also reported by Ray et.al. (1992). The results in Figure 1 show that during the years 2004 the difference between 305-day $M E$ milk yield of summer and winter calving was insignificant. However, during the years $2005(11691 \pm 400 \mathrm{~kg} v s .11483 \pm 410 \mathrm{~kg})$ and $2006(11522 \pm 369 \mathrm{~kg} v s .11041 \pm 374 \mathrm{~kg})$ cow freshening during the summer season gave significantly higher average $M E$ milk yield than those freshening during the winter season.

However, in the year 2007 those freshening during the summer season gave significantly lower 305-day $M E$ milk yield $(10286 \pm 372 \mathrm{~kg})$ than their winter counterparts $(10672 \pm 388 \mathrm{~kg})$. The superiority of the summer freshening over the winter freshening during the years 2005 and 2006, occurred as a result of provision of the efficient cow cooling system. On the other hand the inferiority of the summer freshening in the year 2007 was due to the increase of the numbers of cows without a parallel increase in the cow cooling system a fact that rendered the cooling system inefficient. These results are in agreement with Ray et al. (1992) who reported that in the absence of efficient cooling system, the summer season had significantly lowered 305-days $M E$ milk yield $(7387 \pm 193 \mathrm{~kg})$ than the winter season $(7765 \pm 193 \mathrm{~kg})$ in Arizona.

As it was mentioned above, the effect of year of freshening $\mathrm{x}$ lactation number interaction on 305-days $M E$ milk yield was highly significant $(\mathrm{P} \leq 0.001)$. This interaction is evident in Fig. 2 where the difference among lactation fluctuated with years of freshening. The largest difference observed among lactations in the year 2004, 2005, 2006 and 2007 was 2279, 449, 122 and 1502 kg, re-

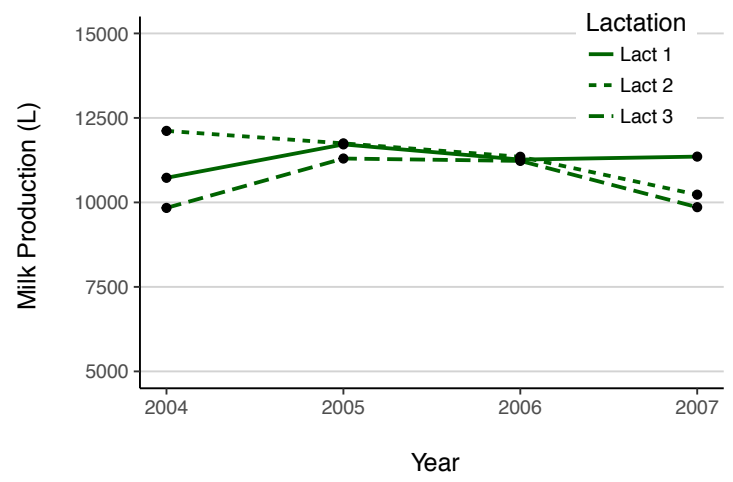

Figure 2. Effect of year and season of lactation number on 305-day $M E$ milk yield.

spectively. The change of differences among lactations, with increasing years might indicate unavoidable management differences from one year to another. Another reason of year of freshening $x$ lactation number interaction was the change in ranking of the lactations with years of freshening. A point to mention is that the second-parity cows had the highest 305-days $M E$ milk yield in the year $2004(12116 \pm 453 \mathrm{~kg})$ while the first lactation cows had the highest 305 day $M E$ milk yield in the years $2007(11355 \pm 407 \mathrm{~kg})$. Another point to mention is that the third-parity cows had the lowest 305-day $M E$ yield throughout the years 2004 to 2007.

The heritability of 305-day $M E$ milk yield was 0.31 . This result is close to the value of 0.29 which was reported by Ojango and Pollott (2001) in Kenya. Estimates of heritability for milk yield from European breeds kept in the tropics were lower than those from similar breeds kept in temperate countries (Lobo et al., 2000). The farm under study imports semen of high quality progeny tested breeding bulls. But a heritability of this magnitude suggests that a successful sire evaluation program could be established.

\section{Conclusion and recommendations}

The least-square mean of 305-day $M E$ milk yield for Holstein Friesian cows was $11060 \pm 355$ kg /305 days/ cow. The effect of genetic (sire of cow) and non genetic interacting factors (year and season of production and lactation number) had significantly affected $M E$ milk yield. The heritability of $M E$ milk yield was 0.31 indicating that improvement programs would be effective. Reproductive performance of Holstein Friesian cattle should be investigated in future studies.

\section{Acknowledgements}

I acknowledge the support of Engineer Abdulla Saif Al Darmaki, Chief Executive Officer of Al Ain Farms for Livestock Production. I would also like to thank Dr. Saleh Abdu Al Shorepy of the University of the United 
Arab Emirates, for his support and excellent information about heat stress. This manuscript was typed and edited by Mr. Walid Mirghany Mohammed of the Department of the President's Affair in UAE.

\section{References}

Armstrong, D.V. 1994. Heat stress interaction with shade and cooling. Journal of Dairy Science, 77: 2044-2050.

Beede, D.K. and Collier, R.J. 1986. Potential nutritional strategies for intensively managed cattle during thermal stress. Journal of Animal Science, 62:543-554.

Bennet, C. 2001. Genetic and management. Virginia Polytechnic Institute. Publication No. 404-084.

Berman, A., Folman, Y. , Kaim, M., Mamen, M., Herz, Z. , Wolfenson, D., Arieli, A. and Graber, Y. 1985. Upper critical temperatures and forced ventilation effects for high-yielding dairy cows in a subtropical climate. Journal of Dairy Science, 68: 1488-1495.

Chase, L.E. 2005. Climate impacts on dairy cattle. Department of Animal Science, Cornell University, Ithaca, NY. Publication No. 14853.

Collier, R.J. 2006. Major advances associated with environmental effects on dairy cattle. Department of Animal Sciences, University of Arizona, Tucson 85721.

Finch, V.A. 1976. An assessment of the energy budget of Boran cattle. Journal of Thermal Biology , 1: 143-148.

Harvey, W.R. 1988. Mixed Model Least-Squares and Maximum Likelihood Computer Program Pc-1 version. Ohio State University.

Intawiwat, N., Wold, J.P., Skaret, J., Rukke, E.O. and Pettersen, M.K. 2013. Minimizing photooxidation in pasteurized milk by optimizing light transmission properties of green polyethylene films. Journal of Dairy Science, 96: 6818-6829.

Johnson, H.D. 1987. Bioclimates and livestock. Bioclimatology and the adaptation of livestock. In: World Animal Science. H.D. Johnson (editor), Elsevier Science Publ. Co., New York.
Lobo, R.N.B., Madalena, F.E. and Vieira, A.R. 2000. Average estimates of genetic parameters for beef and dairy cattle in tropical regions. Abstract. Animal Breeding, 68: 433-462.

Murphy, M.R., Davis, C.L. and McCoy, G.C. 1983. Factors affecting water consumption by Holstein cows in early lactation. Journal of Dairy Science, 66: 35-38.

Ojango, J.M. and Pollott, G.E. 2001. Kenyan farms genetics of milk yield and fertility traits in Holstein-Friesian cattle on large-scale. Journal of Animal Science, 79: $1742-1750$.

Ray, D.E., Halfback, T.J. and Armstrong, D.V. 1992. Season and lactation number effects on milk production and reproduction of dairy cattle in Arizona. Journal of Dairy Science, 75: 2976-2983.

Suleyman, C. 2009. Milk yields traits of Holstein cows at P.S. Farm in Turkey. Journal of Animal and Veterinary Advances 8:6-10. ISSN: 1680-5593 Medwell Journal, 2009.

Suleyman, C.M.E.T. 2006. Calculation of adjustment factors for standardizing actions to mature age and 305-day and estimation of heritability and repeatability of standardized milk yield. Cumhuriyet University, Turkey. Journal of Animal Science, 29: 897-993.

Tao, S. and Dah, G.E. 2013. Invited review: Heat stress effects during late gestation on dry cows and their calves. Journal of Dairy Science , 96: 4079-4093.

Thornton, P.K. 2010. Livestock production: recent trends, future prospects. Philosophical Transactions of Royal Society B, 365: 2853-2867.

Valley Agricultural Software. 2000. Dairy Comp 305, version 2000. Tulare, CA 93274 USA.

Yousef, M. K. 1985. Basic Principles. Stress Physiology in Livestock. Vol. 1. CRC Press, Boca, Raton, FL. 